\title{
Hydrochemical, Isotopic, and Geophysical Studies Applied to the Evaluation of Groundwater Salinization Processes in Quaternary Beach Ridges in a Semiarid Coastal Area of Northern Patagonia, Argentina
}

\author{
Eleonora Carol ${ }^{1, *} \mathbb{\oplus}$, Santiago Perdomo ${ }^{2}$, María del Pilar Álvarez ${ }^{3}$, Carolina Tanjal $^{1}$ and Pablo Bouza ${ }^{4}$ \\ 1 Centro de Investigaciones Geológicas (CIG), Consejo Nacional de Investigaciones Científicas y Técnicas, \\ Universidad Nacional de La Plata, La Plata 1900, Argentina; ctanjal@cig.museo.unlp.edu.ar \\ 2 Centro de Investigaciones y Transferencia del Noroeste de la Provincia de Buenos Aires (CITNOBA), \\ Consejo Nacional de Investigaciones Científicas y Técnicas, Universidad Nacional Noreste de Buenos Aires, \\ Pergamino 2700, Argentina; sperdomo@comunidad.unnoba.edu.ar \\ 3 Instituto Patagónico para el Estudio de los Ecosistemas Continentales (IPEEC), Consejo Nacional de \\ Investigaciones Científicas y Técnicas, Universidad Nacional de la Patagonia San Juan Bosco, \\ Puerto Madryn 9120, Argentina; alvarez@cenpat-conicet.gob.ar \\ 4 Instituto Patagónico de Geología y Paleontología (IPGP-CONICET), Consejo Nacional de Investigaciones \\ Científicas y Técnicas, Universidad Nacional de la Patagonia San Juan Bosco, Puerto Madryn 9120, Argentina; \\ bouza@cenpat-conicet.gob.ar \\ * Correspondence: eleocarol@fcnym.unlp.edu.ar
}

\section{check for}

updates

Citation: Carol, E.; Perdomo, S.; Álvarez, M.d.P.; Tanjal, C.; Bouza, P. Hydrochemical, Isotopic, and Geophysical Studies Applied to the Evaluation of Groundwater Salinization Processes in Quaternary Beach Ridges in a Semiarid Coastal Area of Northern Patagonia, Argentina. Water 2021, 13, 3509. https://doi.org/10.3390/w13243509

Academic Editor: Nicolò Colombani

Received: 27 October 2021

Accepted: 6 December 2021

Published: 8 December 2021

Publisher's Note: MDPI stays neutral with regard to jurisdictional claims in published maps and institutional affiliations.

Copyright: (c) 2021 by the authors. Licensee MDPI, Basel, Switzerland. This article is an open access article distributed under the terms and conditions of the Creative Commons Attribution (CC BY) license (https:/ / creativecommons.org/licenses/by/ $4.0 /)$.

\begin{abstract}
Quaternary sea level fluctuations have led to the development of beach ridges on many South Atlantic coasts. The objective of this paper was to asses from lithological, hydrochemical, isotopic, and geophysical studies the salinization processes affecting groundwater stored in Pleistocene and Holocene beach ridges of the northern Patagonian coast. A hydrogeomorphological characterization of the area was performed using digital elevation models, the interpretation of satellite images, and field studies. Vertical electrical soundings were performed on transects running perpendicular to beach ridges in order to define variations in the freshwater-saltwater interface position. The salinity, chemistry, and stable isotopes of the groundwater were analyzed. The results demonstrated that the groundwater salinization of Pleistocene ridges responds to processes associated with the geological-geomorphological evolution of the area. The cementation of these surface sediments limits rainwater infiltration, which consequently prevents the development of freshwater lenses. This suggests that saline water is the result of ancient marine ingressions. Freshwater lenses develop in Holocene beach ridges; however, slight water salinization is detectable in the most populated areas as a result of intensive exploitation. The data provided are useful for freshwater resource prospection along the arid coast of Patagonia, where beach ridge deposits abound and populations experience serious drinking water supply problems.
\end{abstract}

Keywords: freshwater lenses; vertical electric soundings; water resources; groundwater; semi-arid zone

\section{Introduction}

Quaternary sea level fluctuations that occur as a result of climate change have led to the formation of coastal plains, beach ridges, spits, and sandy bars in coastal areas in many parts of the world $[1,2]$. In coastal plains, groundwater is predominantly saline due to the marine ingressions that originated them and/or the current intrusion of seawater [3]. The low permeability of sediments in coastal plains prevents rainwater from infiltrating and washing salts $[4,5]$. By contrast, beach ridges and spits generally associated with dune fields constitute positive relief morphologies of high permeability where rainwater continuously infiltrates [6-9]. This preferential and localized recharge contributes to the 
development of a freshwater lens that displaces the surrounding saltwater downward by a density difference [10].

This determines that, in many coastal areas of the world, the only freshwater available sources are in the shape of lenses related to beach ridges and dune deposits [11-16]. These freshwater resources are usually relatively small, but significant for the development of coastal populations [17-21].

Freshwater lens salinization is a global issue that deteriorates water supply sources, therefore limiting the population development of coastal areas. This salinization may be due to seawater intrusion due to the intensive exploitation of freshwater lenses [22], by upward flowing of saline groundwater [23,24], or by past marine transgressions [25-28]. In arid and semi-arid areas, salinization problems are accentuated due to scarce and erratic rainfall and the high rate of evaporation that condition aquifers recharge [29-31]. To this end, understanding freshwater-saltwater distribution and the processes leading to water salinization is essential for water resource management in coastal areas [32,33]. Defining the origin is fundamental for groundwater management, since the problem is different if it is marine paleowaters or if it is a seawater intrusion due to anthropic actions. If the increase in salts is due to seawater intrusion, this can be mitigated with sustainable exploitation strategies and with actions that maximize freshwater lens recharge. In this sense, hydrogeochemical, isotopic, and geophysical tools are of importance in the study of the origin and mechanisms of groundwater salinization, e.g., [34-41].

The Patagonian coast of Argentina constitutes an extensive coastal area, in which arid and semi-arid conditions predominate and coastal populations face serious freshwater supply problems [42,43]. Particularly on the coast of Patagonia, the uplift of the area resulted in the preservation of beach ridges generated during different Quaternary ingressions [44-47]. In the northern sector of the coast of Patagonia, in Bahía San Blas (Figure 1), beach ridge deposits can be found, separated by marsh and intertidal plain environments associated with the Jabalí channel (Figure 1). Beach ridges located in a more continental position are associated with an ancient Pleistocene shoreline (MIS 5e), while those located between the Jabalí channel and the sea correspond to a Holocene shoreline (MIS 1) that is currently active $[44,48,49]$. In this arid zone, where annual rainfall and potential evapotranspiration average 300 and $730 \mathrm{~mm}$ [50], respectively, groundwater stored in the shape of freshwater lenses constitutes the only source of supply for local villagers. Previous studies identified the occurrence of predominantly saline groundwater in the Pleistocene ridges and the presence of freshwater lenses in the Holocene (Carol et al., 2021). However, the samples extracted from the Pleistocene ridges were located towards their edges, raising the question of whether the observed behavior occurs in the entire area of Pleistocene beach ridges or only at their edges, adjacent to the intertidal environments. From this arises the need to increase the number of sampling points in the area of Pleistocene ridges, as well as to carry out detailed studies of the sediments that compose both beach ridges, and to define the variation in water salinity in depth. In this context, the aim of this study was to evaluate from hydrochemical, isotopic, and geophysical studies the salinization processes affecting groundwater stored in Pleistocene and Holocene beach ridges of the Bahía San Blas on the northern Patagonian coast. 


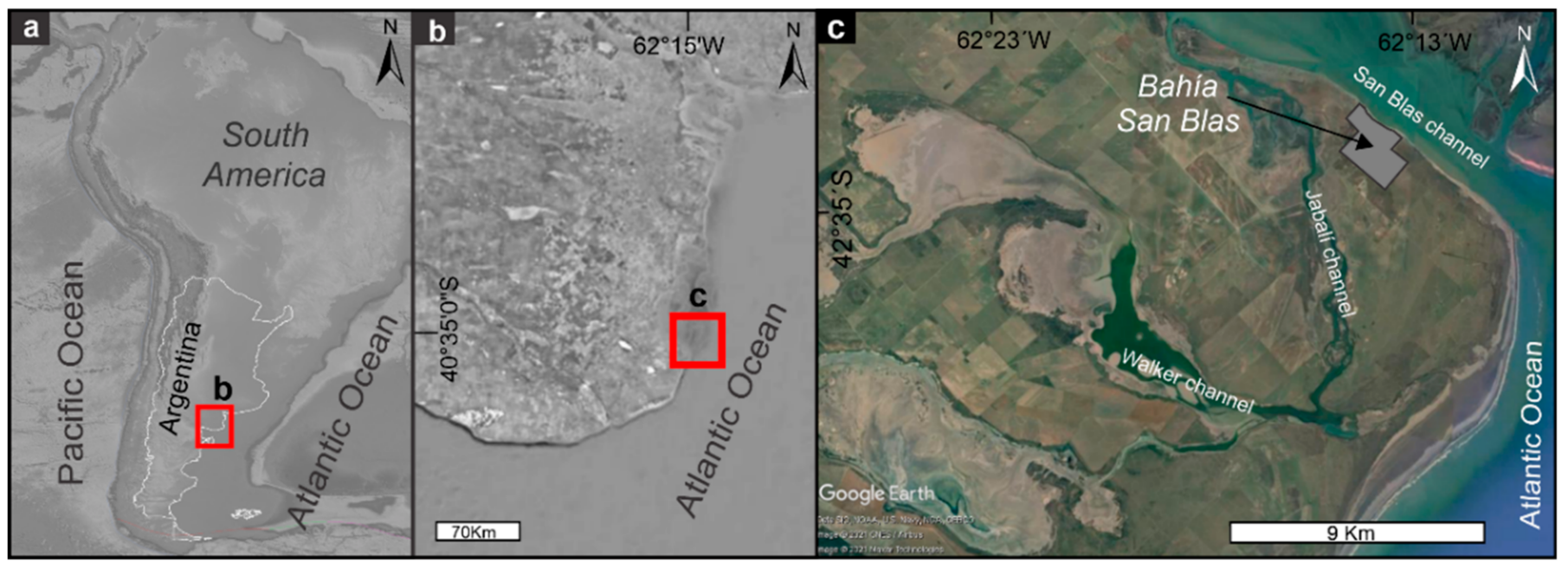

Figure 1. (a) Regional locations of the study area; (b) Location of the study area within the northern Patagonian coast, (c) Bahia San Blas localization.

\section{Materials and Methods}

The geomorphological characteristics of the area were described by means of digital elevation models (DEM) performed by the National Geographic Institute of Argentina (IGN; MDE-Ar v2.0 $30 \mathrm{~m}$ ), the interpretation of satellite images (Google Earth software), and field surveys. The DEM MDE-Ar v2.0 offers a spatial resolution of $30 \mathrm{~m}$ and a vertical accuracy of approximately $2 \mathrm{~m}$ [51]. In addition, the data acquired from these DEMs were also cross-checked with the altimetric information collected in the field with a Trimble ${ }^{\circledR}$ R2 differential GPS consisting of an integrated unit using RTX real-time positioning mode with a horizontal accuracy of $4 \mathrm{~cm}$ and vertical accuracy of $9 \mathrm{~cm}$ (40 points, coinciding with the sampling sites).

During the field surveys, soil trenches and drillings with manual auger (up to $2 \mathrm{~m}$ deep) were performed, and lithological profiles were described in quarries in order to determine the hydrolithological characteristics of the superficial sediments that condition rainwater infiltration.

Vertical electrical soundings (VES) were carried out on transects running perpendicular to the beach ridges to define variations in the freshwater-saltwater interface position. VES data were acquired using a Schlumberger array with a maximum electrode distance of $100 \mathrm{~m}$. During field work, an apparent resistivity curve was obtained after a direct current circulated through the emission circuit and the potential difference generated between the receiver electrodes was measured. The inversion scheme followed here was proposed by [52]; the number of layers was then reduced using the Dar Zarrouk parameters [53] and the response curve was calculated with a linear filter [54]. Additional information was added to adjust the model, especially the thickness or depth of certain layers (manual auger), improving the resistivity determination.

Groundwater samples were obtained from shallow wells (4-8 m deep) and the electrical conductivity (EC), temperature, and $\mathrm{pH}$ of the water were measured in situ using a portable multiparameter (Lutron ${ }^{\circledR}$ WA-2017SD, Lutron Electronics, Coopersburg, PA, USA). The water samples were obtained with polyethylene bottles and the analysis of the major ions was performed in the laboratory at the Centro de Investigaciones Geológicas (Geological Research Center) using standardized methods [55]. The carbonate $\left(\mathrm{CO}_{3}{ }^{2-}\right)$, bicarbonate $\left(\mathrm{HCO}_{3}{ }^{-}\right)$, chloride $\left(\mathrm{Cl}^{-}\right)$, calcium $\left(\mathrm{Ca}^{2+}\right)$, and magnesium $\left(\mathrm{Mg}^{2+}\right)$ were determined by titration; the sodium $\left(\mathrm{Na}^{+}\right)$and potassium $\left(\mathrm{K}^{+}\right)$by flame photometry; and the sulfate $\left(\mathrm{SO}_{4}{ }^{2-}\right)$ by UV-Visible spectrophotometry. The determination of the saturation indexes (SI) was conducted using the PHREEQC software [56].

The analysis of stable isotopes in water $\left(\delta^{2} \mathrm{H}\right.$ and $\left.\delta^{18} \mathrm{O}\right)$ was performed in some samples at the Universidad Nacional de San Luis (National University of San Luis), following 
the Cavity Ring-Down Spectroscopy (CRDS) methods, using a Picarro L2120-i coupled to a high-precision vaporizer A0211. The isotopic results are expressed as $\delta \%$, defined as $\delta=1000(\mathrm{Rs}-\mathrm{Rr}) / \mathrm{Rr} \%$, where $\delta$ is the isotopic deviation in \% relative to Vienna Standard Mean Ocean Water (V-SMOW) [57]; s: sample; r: International reference; R: isotopic ratio $\left({ }^{2} \mathrm{H} /{ }^{1} \mathrm{H},{ }^{18} \mathrm{O} /{ }^{16} \mathrm{O}\right)$. The analytical accuracy is $\pm 0.05 \%$ and $\pm 0.5 \%$, for $\delta^{18} \mathrm{O}$ and $\delta^{2} \mathrm{H}$, respectively.

The freshening and salinization processes were analyzed using a hydrochemical facies evolution diagram, HFE-D [58], ionic and isotopic relationships graphs, and water mixing calculations. To evaluate the freshwater lens recharge from rainwater, isotopic values were compared with the local meteoric line $\delta^{2} \mathrm{H}=7.73 \pm 0.28 \times \delta^{18} \mathrm{O}+8.89 \pm 1.67$ [59], these being the closest data for a coastal area. Theoretical water mixtures were obtained considering as end members the average chemical and isotopic composition of fresher water samples $(C f w)$ and the seawater sampled from the Jabalí channel (Csw).

$$
C_{0}=y C s w+(1-y) C f w
$$

where $y$ is the percentage of seawater and $(1-y)$ the percentage of freshwater in the lenses.

\section{Results}

\subsection{Geomorphological and Hydrolithological Characterization}

Field work supported by DEM and satellite image analysis enabled the geomorphological characterization of the Pleistocene and Holocene beach ridge deposits. Pleistocene beach ridges comprise a series of linear deposits with a prevailing N-S orientation separated by more depressed areas. These ridges reach heights of about $12 \mathrm{~m}$ a.s.l., while in depressed areas, the heights vary between 0.5 and $4 \mathrm{~m}$ a.s.l. Depressed areas could have constituted ancient coastal lagoons or ancient intertidal channels (Figure 2a).

The more superficial sediments in these beach ridges comprise high-permeability gravels and sands (Figure 2b), observing from a depth of $50 \mathrm{~cm}$ levels of gravel cemented by carbonates (Figure 2c,d). In addition, in mills' large-diameter excavations, the presence of a cemented sandstone level was noticed at a $3 \mathrm{~m}$ depth, which constituted the base up to where the supply perforations were made.

Holocene beach ridges originated as a beach ridge plain developed in the $\mathrm{N}-\mathrm{S}$ direction that diffracted in the N sector towards the NW due to the coastal drift that currently originates and models the current deposits of the barrier spit. The highest heights of Holocene beach ridges ( $8 \mathrm{~m}$ a.s.l.) are found in the central sector, decreasing both towards the north end of the spit, and the sea and Jabalí channel (Figure 2a).

Within Holocene ridges, spatial variations in the hydrolithological characteristics of the superficial sediments are observed; all are associated with high-permeability lithologies. In the $\mathrm{N}$ sector at the tip of the spit where heights do not exceed $5 \mathrm{~m}$ a.s.l., the superficial sediments are composed of gravels with a sandy matrix (Figure 2e) passing to predominantly gravel deposits on the edges of the spit, limiting both the sea and the Jabali channel. In the central part of the spit, sediments are gravelly, although the percentage of sand in the matrix increases; levels of interbedded sand in the gravel deposits are also observed (Figure 2f). In the $\mathrm{S}$ sector, sandy deposits of coastal dunes develop on the surface (Figure 2g), mainly in areas close to the sea. On the other hand, towards the Jabali channel, dune deposits are scarce and the superficial sediments comprise gravel with a sandy matrix. 


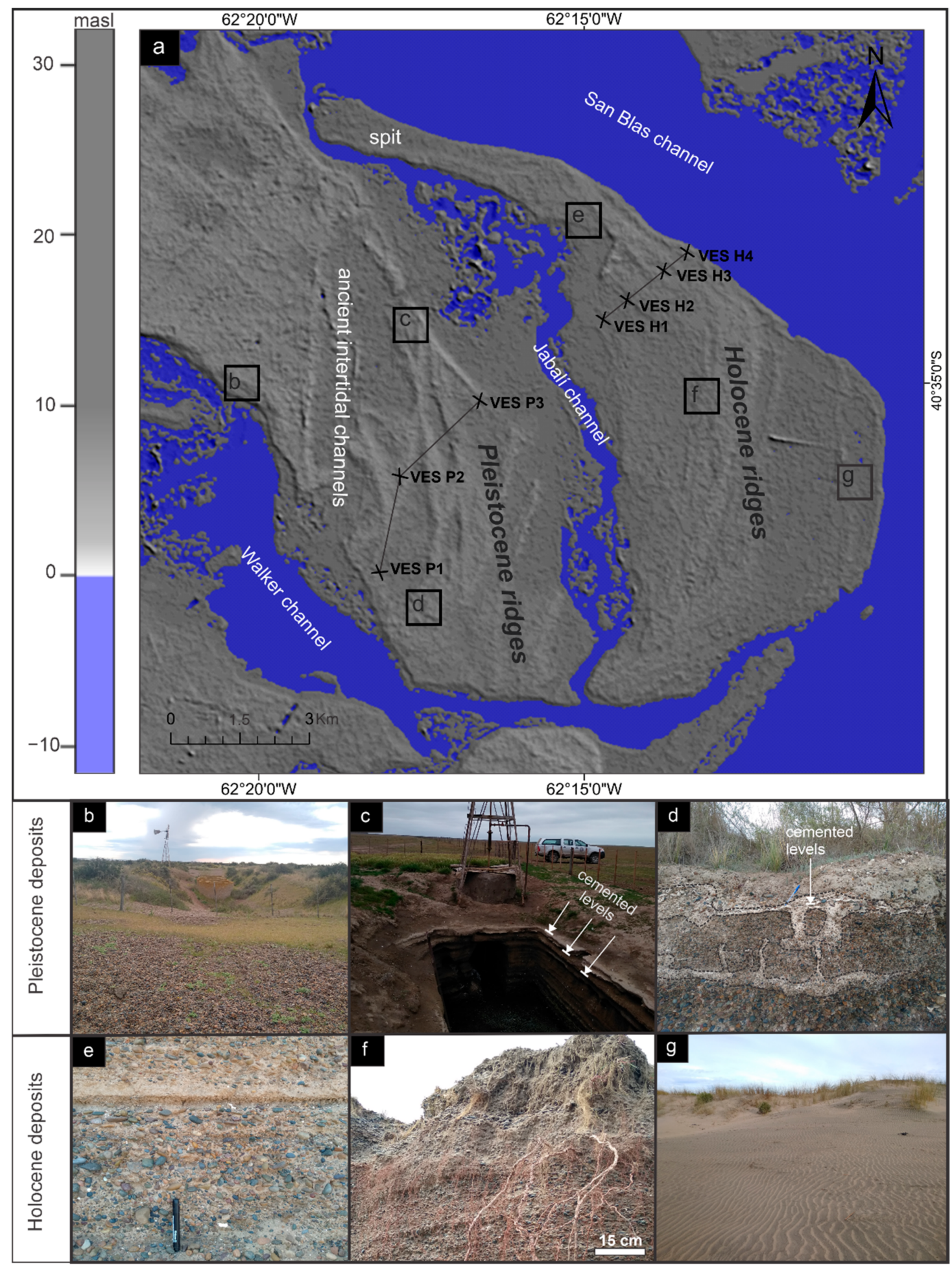

Figure 2. (a) Digital elevation model where the disposition of Pleistocene and Holocene beach ridges is indicated; (b) Pleistocene beach ridges with groundwater catchments; (c) groundwater catchment well where cemented levels are observed within Pleistocene deposits; (d) ground section where the cemented levels are observed within the Pleistocene deposits; (e,f) Holocene stratified gravel deposits with different percentages of the sandy matrix; (g) Holocene deposit of sand. 


\subsection{Geophysical Data}

The recorded curves demonstrate a great contrast in the apparent resistivity values, with differences of almost two orders of magnitude (1000 to $10 \mathrm{Ohm} \mathrm{m}$ ). The general behavior of the curves starts with high values, which then follow a decreasing trend in the measured values. The proposed models feature an adjustment error (root mean square) of less than $5 \%$ between the observed and calculated curves. In the proposed resistivity models, it is recognized that the first layers are of high resistivity; later, a sequence of intermediate resistivity layers supported on a very low resistivity base can be observed.

The geophysical models proposed for Pleistocene ridges (VES P1, P2, and P3) demonstrate that the unsaturated zone presents resistivity values of 6 to $15 \mathrm{Ohm} \mathrm{m}$ (Figure 3). In the VES P1, a sequence of layers of higher resistivity (200 and $250 \mathrm{Ohm} \mathrm{m}$ ) is observed, probably due to a lithological change. The phreatic aquifer in this sector is characterized by layers of very low resistivity (less than $5 \mathrm{Ohm} \mathrm{m}$ ) associated with the presence of brackish water.

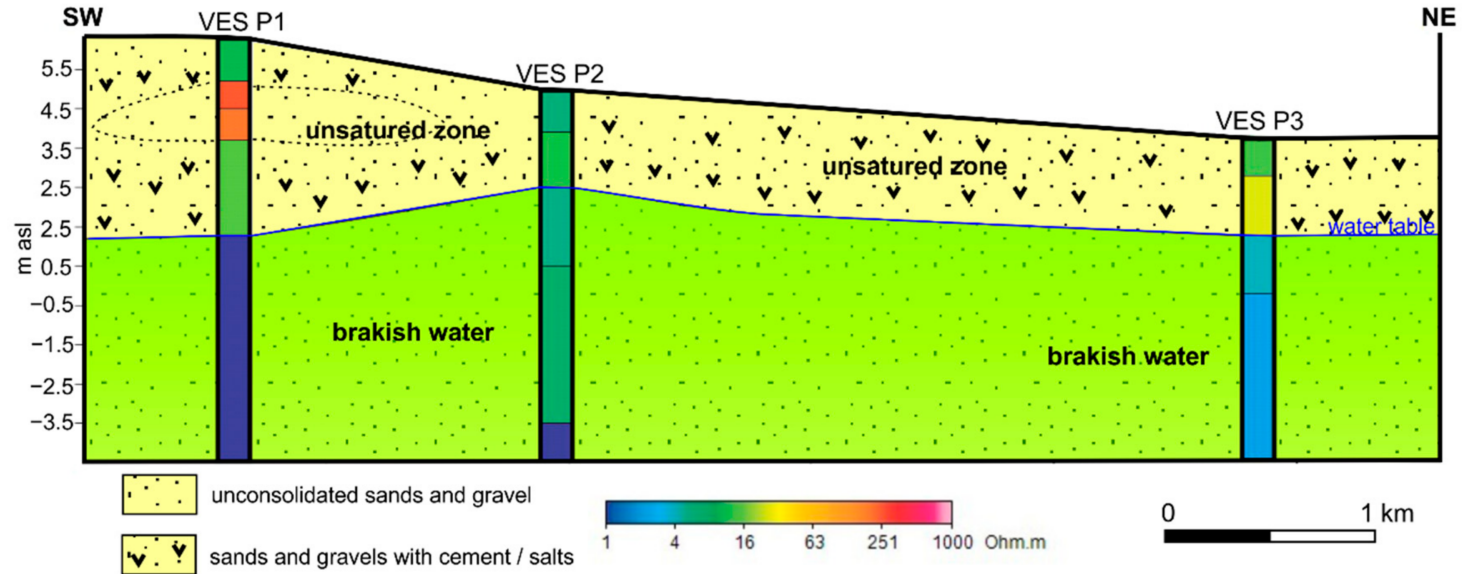

Figure 3. Vertical electric soundings of Pleistocene beach ridges.

In the integrated geophysical models on the Holocene ridges, the unsaturated zone demonstrated higher resistivity values (more than $100 \mathrm{Ohm} \mathrm{m}$ ) in the topographically higher sector (VES H3 and H4), while in the lowest one, it displayed low resistivity (8 and $9 \mathrm{Ohm} \mathrm{m}$ ) (Figure 4). The phreatic aquifer presented an intermediate resistivity (60 Ohm m) in the VES H2 and H3, attributable to freshwater and lower values (less than $5 \mathrm{Ohm} \mathrm{m}$ ) in the VES H1 and H4, possibly caused by an increase in EC of the water (higher salinity) (Figure 4).

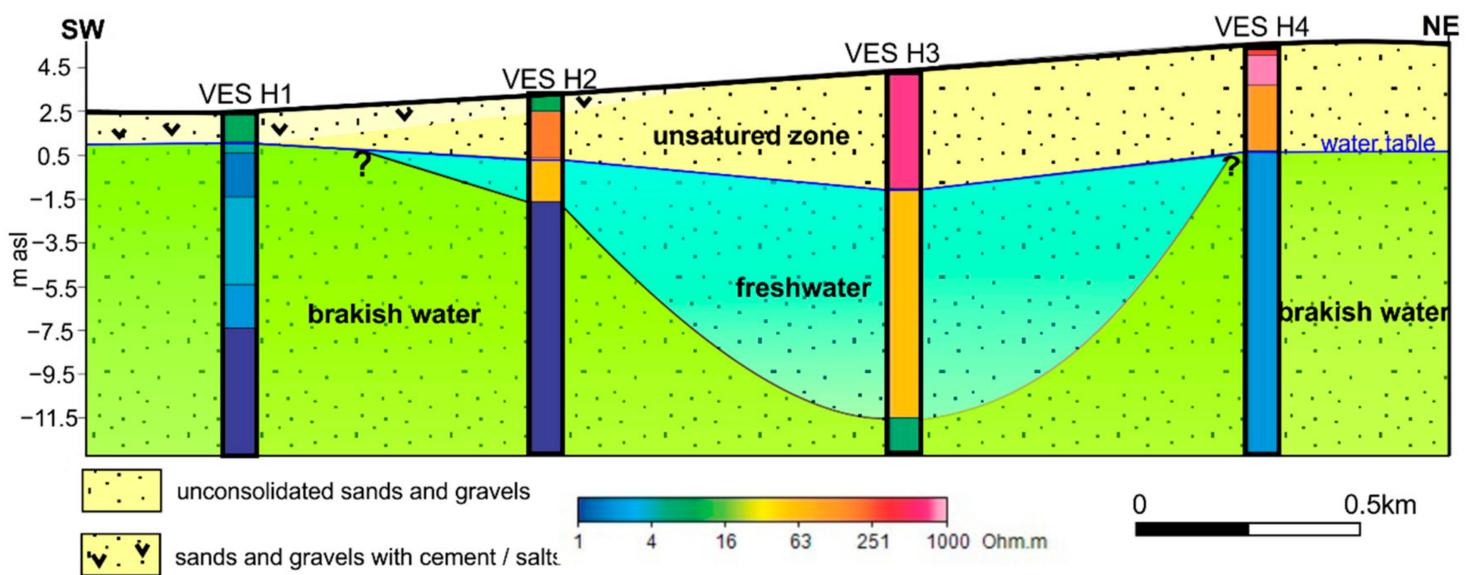

Figure 4. Vertical electric soundings of Holocene beach ridges. 


\subsection{Hydrochemistry and Stable Isotopes}

The analysis of EC values and major ions contents demonstrated sharp differences between the groundwater samples from the Pleistocene and Holocene beach ridges. The Pleistocene beach ridges were distinguished by high saline groundwater (with EC values between 5160 and 16,860 $\mu \mathrm{S} / \mathrm{cm}$ ), while in the Holocene ridges, groundwater salinity was lower in most samples (EC less than $2000 \mu \mathrm{S} / \mathrm{cm}$ ). EC values between 2000 and $5150 \mu \mathrm{S} / \mathrm{cm}$ were recorded in the wells located in the most populated sector and the three wells in the S sector. On the other hand, only one groundwater sample from the Holocene ridges registered high salinity values (EC of $7960 \mu \mathrm{S} / \mathrm{cm}$ ); it was located close to the tip of the spit (Figure 5).

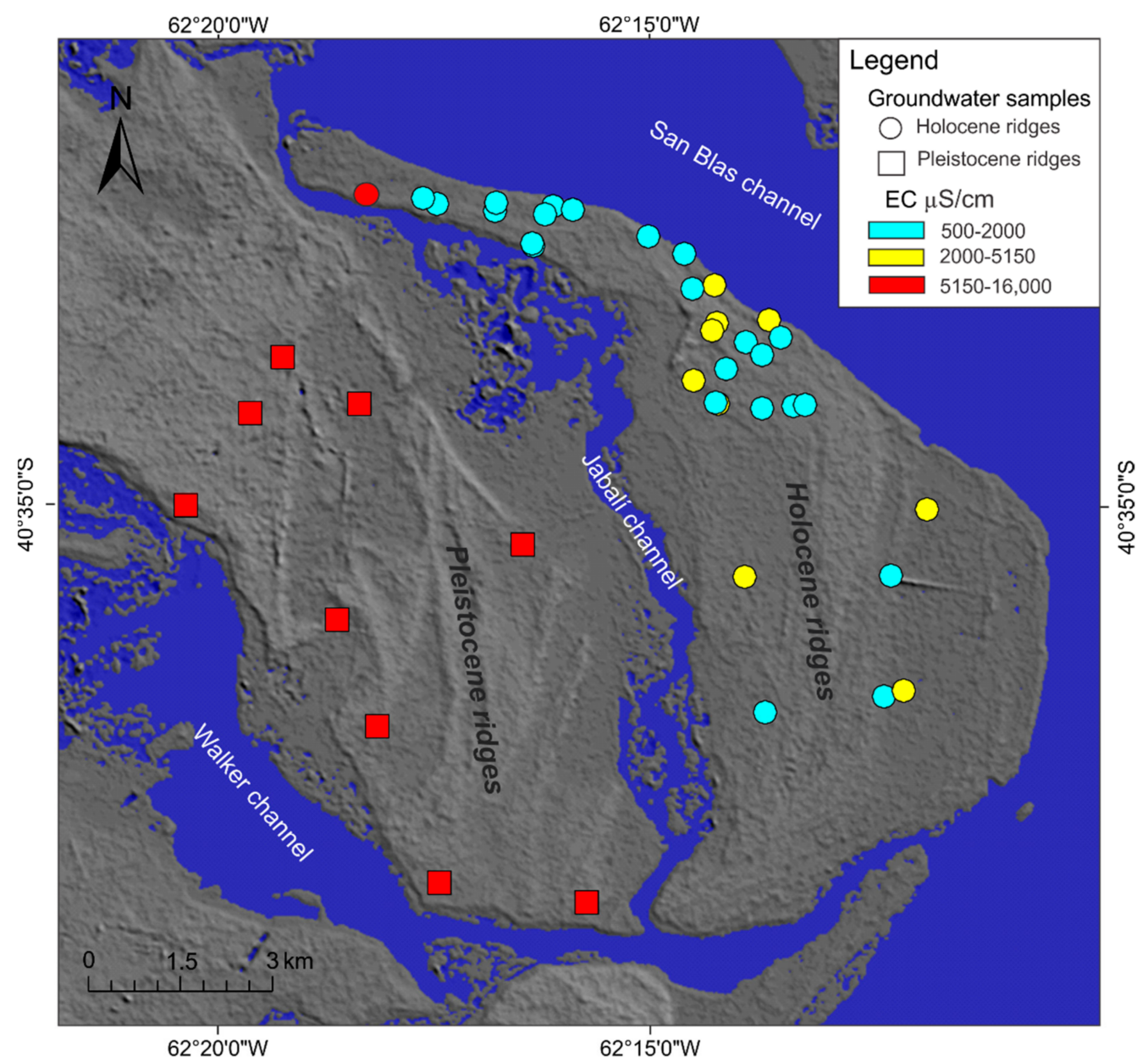

Figure 5. Map showing the location of the points where groundwater samples were taken with their electrical conductivity (EC) values.

The hydrochemical facies evolution diagram, HFE-D [58] also demonstrates a clear differentiation between groundwater samples from the Pleistocene and Holocene ridges (Figure 6). In the Pleistocene beach ridges, groundwater is $\mathrm{Na}-\mathrm{Cl}$ and is located along with seawater samples at the extreme associated with salinization processes of marine origin. Conversely, groundwater in the Holocene ridges moved from $\mathrm{Na}-\mathrm{Cl}$ to $\mathrm{Na}-\mathrm{HCO}_{3}$ facies; this variation was accompanied by a decrease in the EC (freshening trend). 


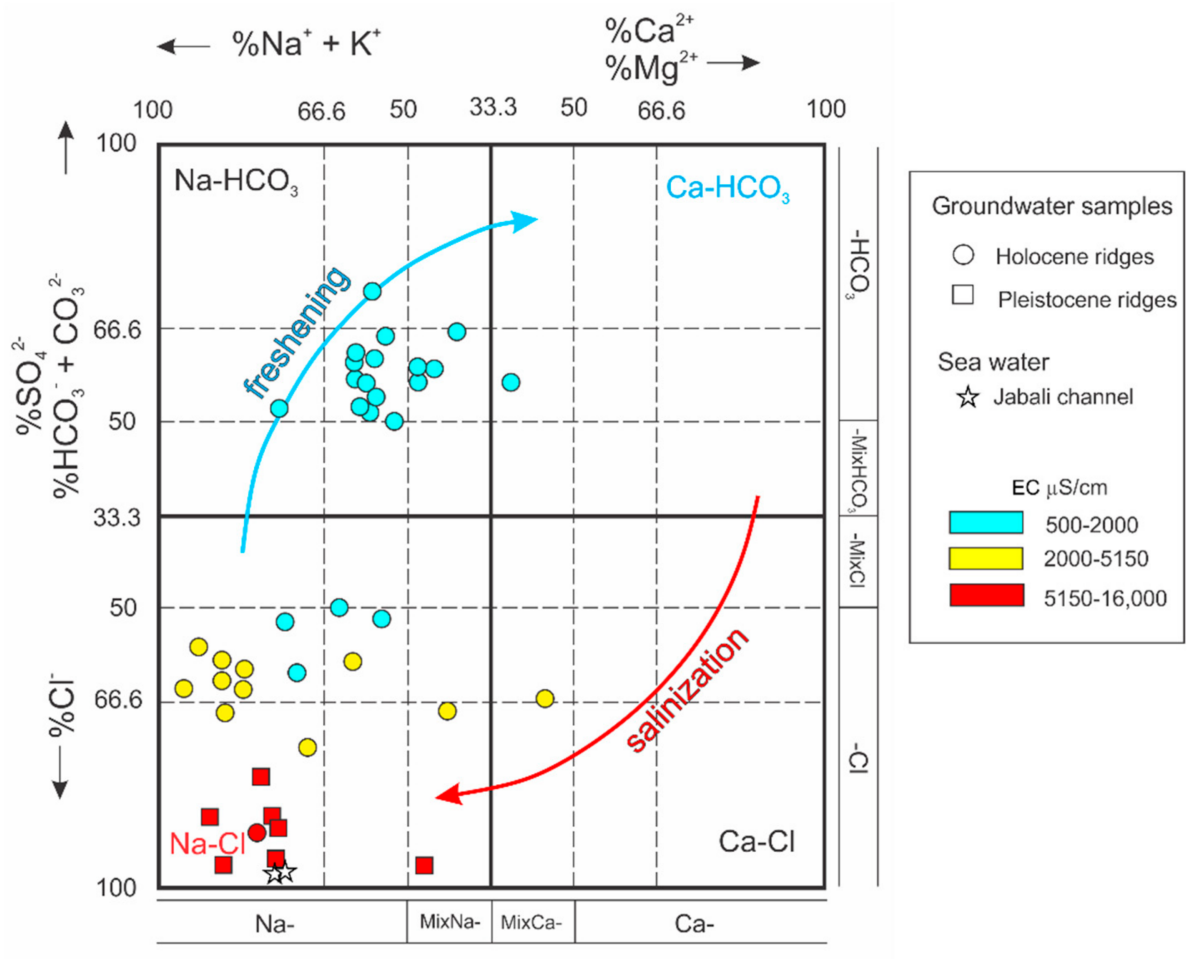

Figure 6. Hydrochemical facies evolution diagram, HFE-D [51].

The salinization trends associated with seawater in Pleistocene ridges and those of freshening in the Holocene ridges were also reflected in the isotopic contents and major ions relations (Figure 7). Groundwater samples from Pleistocene ridges displayed isotopic values between -35.0 and $-33.5 \%$ and between -5.2 and $-4.6 \%$ of $\delta^{2} \mathrm{H}$ and $\delta^{18} \mathrm{O}$, respectively. In the $\delta^{2} \mathrm{H}$ vs. $\delta^{18} \mathrm{O}$ plot (Figure 7a) they were located around a mixing line whose end member values corresponded to the average isotopic composition of the fresher water samples and the seawater sampled from the Jabalí channel. Within this theoretical mixing line, the isotopic values of the groundwater of the Pleistocene ridges were associated with mixing percentages, with seawater contributions of up to $20 \%$. This trend towards salinization associated with seawater inputs was also observed in both $\delta^{18} \mathrm{O}$ vs. $\mathrm{Cl}^{-}$and $\mathrm{Na}^{+}$vs. $\mathrm{Cl}^{-}$ratios (Figure $7 \mathrm{~b}, \mathrm{c}$ ). Note that in the $\mathrm{Na}^{+}$vs. $\mathrm{Cl}^{-}$ratio, when plotting other samples of Pleistocene ridges that did not featured isotopic values but instead featured major ion determinations, seawater contributions in the theoretical mixtures reached values of up to $32 \%$. Conversely, the $\mathrm{Na}^{+}-\mathrm{Cl}^{-}$vs. $\left(\mathrm{HCO}_{3}{ }^{-}+\mathrm{SO}_{4}{ }^{2-}\right)-$ $\left(\mathrm{Ca}^{2+}+\mathrm{Mg}^{2+}\right)$ ratio demonstrated that samples were located around the 1:1 line, indicative of cation exchange processes, with the largest part of the samples located in the release Ca-fixation Na field (Figure 7d). Additionally, the $\mathrm{Ca}^{2+} / \mathrm{Na}^{+}$ratio in the samples from the Pleistocene ridges was low and similar to that of seawater; this trend was maintained with the increase in $\mathrm{Cl}^{-}$(Figure 7e).

The samples corresponding to Holocene beach ridges presented isotopic values between -5.75 and -5.20 of $\delta^{18} \mathrm{O}$ and between -35.00 and -33.50 of $\delta^{2} \mathrm{H}$. In the $\delta^{2} \mathrm{H}$ vs. $\delta^{18} \mathrm{O}$ graph (Figure 7a), they are located close to the local meteoric line [59], indicating recharge from rainwater infiltration. The scarce isotopic variation and the low $\mathrm{Cl}^{-}$content of these samples suggests that the samples with the least saline were located at the extreme representation of freshwater in the graph $\delta^{18} \mathrm{O}$ vs. $\mathrm{Cl}^{-}$, while those that presented EC values between 2000 and $5150 \mu \mathrm{S} / \mathrm{cm}$ moved towards the mixing line with seawater contributions lower than $5 \%$, reaching $11 \%$ in the higher-saline sample (Figure $7 \mathrm{~b}$ ). This tendency and mixing of percentages were in turn evidenced in the $\mathrm{Na}^{+} \mathrm{vs} . \mathrm{Cl}^{-}$ratio (Figure 7c). 

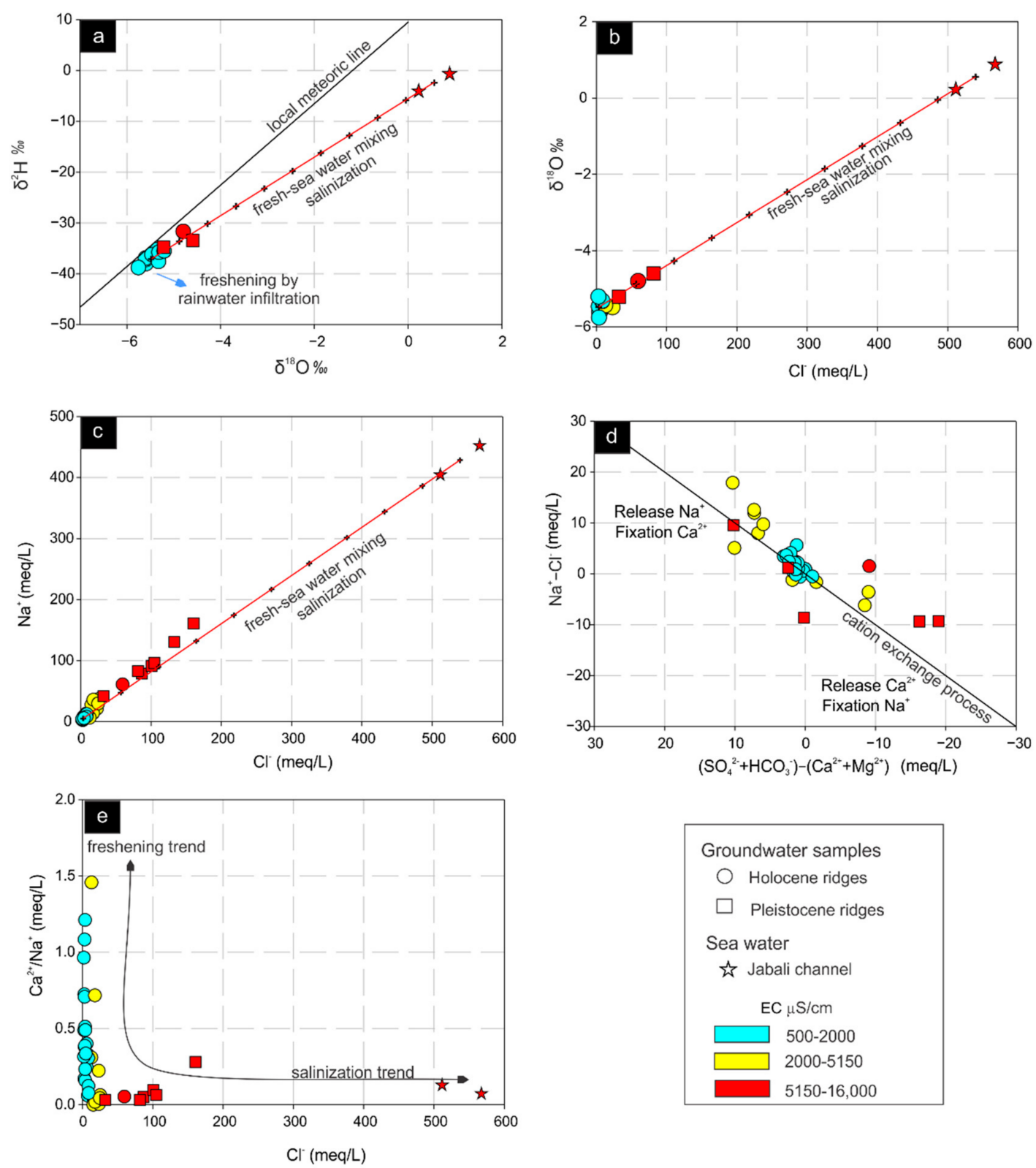

Figure 7. Stable isotope and ionic ratios of groundwater samples. (a) $\delta^{2} \mathrm{H}$ vs. $\delta^{18} \mathrm{O}$, (b) $\delta^{18} \mathrm{O}_{\text {vs. }} \mathrm{Cl}^{-},\left(\right.$c) $\mathrm{Na}^{+}$vs. $\mathrm{Cl}^{-}$, (d) $\mathrm{Na}^{+}-\mathrm{Cl}^{-}$vs. $\left(\mathrm{HCO}_{3}{ }^{-}+\mathrm{SO}_{4}{ }^{2-}\right)-\left(\mathrm{Ca}^{2+}+\mathrm{Mg}^{2+}\right),(\mathbf{e}) \mathrm{Ca}^{2+} / \mathrm{Na}^{+}$vs. $\mathrm{Cl}^{-}$.

The $\mathrm{Na}^{+}-\mathrm{Cl}^{-}$vs. $\left(\mathrm{HCO}_{3}{ }^{-}+\mathrm{SO}_{4}{ }^{2-}\right)-\left(\mathrm{Ca}^{2+}+\mathrm{Mg}^{2+}\right)$ ratio demonstrated that the samples were located around the 1:1 line, indicative of cation exchange processes (Figure 7d); however, in the lower-saline samples, the values of $\mathrm{Na}^{+}-\mathrm{Cl}^{-}$and $\left(\mathrm{HCO}_{3}{ }^{-}\right.$ $\left.+\mathrm{SO}_{4}{ }^{2-}\right)-\left(\mathrm{Ca}^{2+}+\mathrm{Mg}^{2+}\right)$ were very close to zero. In general, the samples of Holocene ridges presented high $\mathrm{Ca}^{2+} / \mathrm{Na}^{+}$ratios and low concentrations of $\mathrm{Cl}^{-}$following freshening trends (Figure 7e).

\section{Discussion}

Beach ridges deposited during the quaternary in the Bahía San Blas area constitute topographically positive geoforms, composed of coarse-grained sediments (gravel and sand), where freshwater lenses could be stored. Despite this, the presence of carbonate cementation recorded in Pleistocene ridges and the absence of cement in the Holocene ridges represents a hydrolithologically relevant difference conditioning the development of freshwater lenses. 
In the Pleistocene beach ridges, layers of gravel and cemented sands were recorded both in shallow perforations and in road outcrops. Their presence was also displayed in the geophysical studies (Figure 3), which characterized the unsaturated zone of these beach ridges by low resistivity values (values of 6 to $15 \mathrm{Ohm} \mathrm{m}$ ). This type of carbonatic cement filling spaces between gravels and sands, causing a strong decrease in the permeability of the sediments, has been described in coastal sectors of northern Patagonia as well [60]. The decrease in permeability due to cementation limits rainwater infiltration, consequently hindering freshwater lens development. Geophysical and hydrochemical studies evidence the absence of freshwater in the entire Pleistocene beach ridge area. Geophysical studies (Figure 3) demonstrated the presence of low resistivity levels (less than $5 \mathrm{Ohm} \mathrm{m}$ ) below the electro-layer associated with the unsaturated zone, which was related to high-salinity groundwater. In addition, groundwater EC measurements in this area were in all cases higher than $5150 \mu \mathrm{S} / \mathrm{cm}$ (Figure 5). Regarding the origin of this salinity, chemical and isotopic signals would indicate that it is primarily marine. In the hydrochemical facies evolution diagram, HFE-D [58], it is demonstrated that in Pleistocene beach ridges, $\mathrm{Na}-\mathrm{Cl}$ facies dominate, with clear salinization trends associated with seawater (Figure 6). Similar hydrochemical trends of salinization by seawater mixing are seen in isotopic and ionic ratios (Figure $7 \mathrm{a}-\mathrm{c}$ ). In the isotopic ratio $\delta^{2} \mathrm{H}$ vs. $\delta^{18} \mathrm{O}$ (Figure 7a), the analyzed samples register seawater contributions of up to $20 \%$; however, the presence of more saline waters than those with isotopic data and that present similar $\mathrm{Na}^{+}$vs. $\mathrm{Cl}^{-}$trends (Figure $7 \mathrm{c}$ ) displaying, in some sectors, higher mixing percentages (up to 32\%).

In contrast to the Pleistocene ridges, the Holocene beach ridges were composed of loose sands and gravels without cementation (Figure 2). The unsaturated zone in these ridges presented higher resistivity values (more than $100 \mathrm{Ohm} \mathrm{m}$ ), while towards the Jabalí channel (VES H1) in marsh edge environments with saline soils, the resistivity was low ( 8 and $9 \mathrm{Ohm} \mathrm{m}$ ). The high permeability of the sediments constituting these beach ridges enables rapid rainwater infiltration and the development of freshwater lenses. The presence of fresh groundwater was verified through geophysical and hydrochemical studies. In the central sectors of beach ridges, VES demonstrated that under the electro-layer corresponding to the unsaturated zone, another layer, with high resistivity corresponding to a groundwater level of low salinity, develops (Figure 4). Additionally, it was observed that this lens is very thin and is salinized both towards the west and east, where it is bordered by the marsh and the sea, respectively. Towards the Jabali channel in the topographically low sectors close to the marsh, VES indicates the existence of low-resistivity electro-layers associated with the proximity of shallow and saline groundwater. On the other hand, towards the sectors next to the sea, below the electro-layer corresponding to the unsaturated zone, the presence of an electro-layer with resistivities close to $25 \mathrm{Ohm}$, characteristic of brackish water, was observed. Thereby, freshwater lenses would develop in the central sectors, where beach ridge deposits present higher topographic heights. Similarly, it is important to note that the freshwater thicknesses estimated from the VES were less than $5 \mathrm{~m}$ and that VES H3 located in the central part of the ridges presented a depression in the water table. Considering that this VES is located in the most populated sector, where there are a large number of household wells, this decrease in the water level would suggest intensive exploitation of the aquifer. EC measurements carried out in different sectors of the Holocene ridges mainly presented low-salinity water (less than $2000 \mu \mathrm{S} / \mathrm{cm}$ ). In the populated area and some topographically low sectors located to the south, EC tends to increase, registering saline water only in a well located at the north end of the spit (Figure 5). The groundwater isotopic ratio $\delta^{2} \mathrm{H}$ vs. $\delta^{18} \mathrm{O}$ (Figure $7 \mathrm{a}$ ), with similar values to the meteoric line, indicates that rainwater infiltrates rapidly in these ridges, recharging the freshwater lens. The processes of freshening and the associated cation exchange are evidenced in the hydrochemical facies evolution diagram, HFE-D [51], and in the ratios of $\mathrm{Na}^{+}-\mathrm{Cl}^{-}$vs. $\left(\mathrm{HCO}_{3}{ }^{-}+\mathrm{SO}_{4}{ }^{2-}\right)-\left(\mathrm{Ca}^{2+}+\mathrm{Mg}^{2+}\right)$ and $\mathrm{Ca}^{2+} / \mathrm{Na}^{+}$(Figures 6 and $7 \mathrm{~d}$ ). In the HFE-D diagram and both the isotopic and $\mathrm{Na}^{+} \mathrm{vs} . \mathrm{Cl}^{-}$ratios, slight salinization 
trends are recorded in the wells with the highest EC, primarily located in the populated area (Figures 6 and $7 \mathrm{a}-\mathrm{c}$ ).

Albeit with different magnitudes, groundwater salinization occurs in both Pleistocene and Holocene beach ridges. However, as explained above, changes in sediment permeability condition the development of freshwater lenses. The joint analysis of the results allowed us to identify that there are different salinization processes. These salinization processes would be geogenic in Pleistocene ridges and mainly anthropic in the Holocene ridges.

Groundwater salinization in Pleistocene ridges is geogenic and would respond to processes associated with the quaternary geological-geomorphological evolution itself. Quaternary is characterized by sea-level oscillations that gave rise to the deposition of beach ridges. In Bahía San Blas, beach ridges have been identified whose deposits represent at least MIS 5e and MIS 1 transgressive episodes resulting from the cortical uplift in Patagonia $[44,46,49]$. In addition, there were marked climatic changes during this period, with evidence that after MIS 5e, beach ridges were exposed on the surface affected by geomorphic and pedogenetic processes, the latter identified by the presence of calcretes, which mainly developed in the upper part of the gravel deposits, in the boundary with the overlying sandy Holocene deposits $[61,62]$. The presence of pedogenetic carbonates would indicate arid and semi-arid conditions [63]. Among the factors that favor cementation by carbonate precipitates, there are those associated with lithological changes. Sandy soils occurrence, which is in many cases associated with aeolian deposits above the gravel deposits of beach ridges, favors the precipitation of carbonates. This is due to the infiltrating water being retained before reaching the pressure necessary to fill the larger pores of the underlying horizon $[64,65]$. At this granulometric boundary, the solution becomes concentrated as water is removed by evapotranspiration; therefore, salts and pedogenic carbonate accumulations form in/or near upper gravel deposits [66]. In this way, different cemented levels may exist in some areas (Figure 2c,d), depending on the diverse processes that have led to their cementation. These cemented layers would later function as impermeable or very low-permeability levels conditioning rainwater infiltration, consequently preventing freshwater lenses development. On the other hand, it is interpreted that salinization by seawater intrusion evidenced in the chemical and isotopic signal of water could not be current. This is because the current sea level could not generate a marine intrusion that influences the entire area of Pleistocene ridges, which are topographically higher than Holocene ridges. Due to this, it is to be expected that the marine intrusion affecting Pleistocene ridges would have occurred during MIS 1 along with the marine ingression that led to the deposition of Holocene ridges, specifically during the climatic optimum or Hypsithermal (Hypsithermal ca. 6000 yr. BP). In this ingression, although the sea level does not cover Pleistocene ridges, it could cause seawater intrusion in them. During the climatic optimum, only Pleistocene ridges above approximately $7 \mathrm{~m}$ a.s.l. would have remained above sea level. Sea would have entered not only from the east, but also from the west due to the flooding of what is currently the Walker channel, and could also flood the lowlands that cross Pleistocene ridges (Figure 2). Later, with sea level decrease, regardless of the existence of wet periods, the presence of cemented layers from MIS 5a would limit rainwater infiltration and consequently would prevent the formation of freshwater lenses in these ridges that can displace saline water. For this reason, groundwater currently reflects a chemical and isotopic signal of mixing with seawater, where scarce rainfall hinders freshwater lens development as a separate phase from that of seawater. A scheme of the quaternary evolution of the area is shown in Figure 8.

Changes in coastline position as a result of sea-level change cause an imbalance between the groundwater and seawater interface position and the present-day sea level [67-69]. Aquifer salinization by Quaternary marine ingressions with chemical signals of mixing with seawater has been recorded in other coastal aquifers in the region [70-72]. This also occurs in other areas worldwide, where groundwater and seawater interface positions are a result of late Quaternary paleoenvironmental conditions [15,73-75]. In other regions, these salinization processes due to paleo-intrusions are compounded by the dissolution 
of evaporites formed during arid periods, which causes the salinity of groundwater to be higher than that of seawater, (e.g., Laizhou Bay in China [76,77]). By contrast, in other regions of the world, the deglaciation that led to the sea level rise during the Pleistocene favored the recharge of aquifers with fresh water from melting ice, causing the freshening of seawater by dilution, (e.g., in the Ledo-Paniselian aquifer in Flanders, Belgium [78]). Likewise, areas of extreme aridity (Sahara desert) currently feature freshwater aquifers that were recharged during rainy periods in the Pleistocene. All these examples demonstrate how the Quaternary geological and climatic evolution of an area conditions groundwater chemistry, which may not respond to current water balances [79].
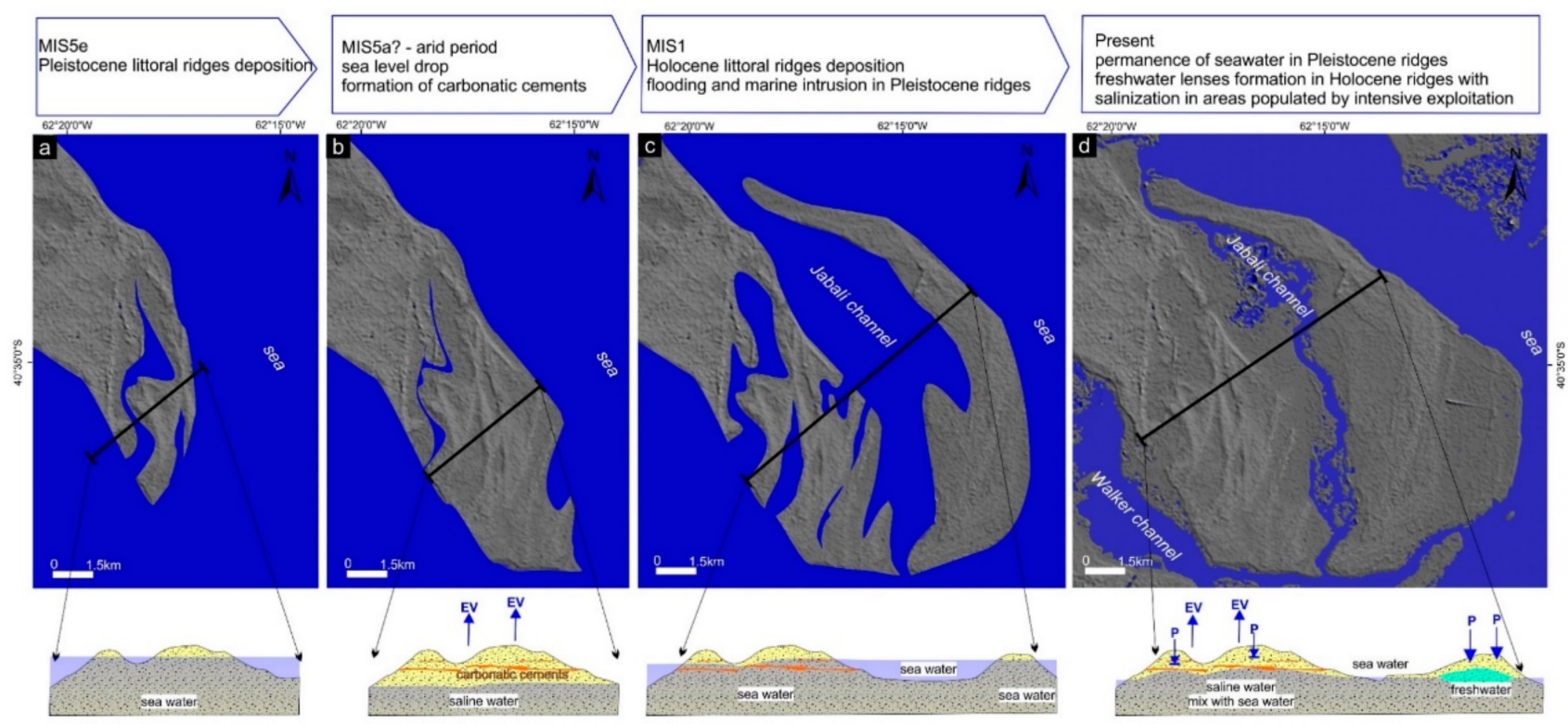

Figure 8. Diagram showing geological-geomorphological evolution and processes of salinization and formation of freshwater lenses. (a,b) MIS 5 ( 75-130 ka); (c) Hypsithermal ( 6 ka); (d) present day.

Conversely, Holocene ridges in their most recent geological-geomorphological evolution have not undergone periods of aridity capable of forming carbonate cement, or have not formed for a sufficient amount of time. This makes its gravel and sandy sediments maintain the high permeability that allows the rapid infiltration of rainwater. Despite this, scarce water excesses in the area [50] determine the development of thin freshwater lenses (Figure 8d). In these lenses, incipient salinization processes were recorded in the central part of the ridges where the San Blas population is concentrated. As a consequence, water level depression was measured (VES H3 in Figure 4) that not only decreases the thickness of the freshwater lens but also causes an increase in the EC (Figure 3). Therefore, the groundwater salinization of Holocene ridges is associated with anthropically induced processes. Intensive exploitation is the main cause of coastal aquifer salinization on a global scale, e.g., [80-83]. The increased rate of abstraction due to higher water demand has generated significant challenges to sustainable fresh groundwater management, especially to the effective prevention of coastal aquifer salinization [22,27]. This situation is even more serious in coastal aquifers in arid and semi-arid areas, where the freshwater lenses stored are thin due to scarce water excess, which makes them very vulnerable [31]. In addition to this problem, there is the associated regional climatic trend of increasingly arid conditions, generating a decrease in groundwater recharge. Faced with this situation, the need to propose management guidelines to control freshwater lens exploitation arises in order to achieve sustainable pumping that preserves the only freshwater resource in the region. Furthermore, in order to assess the vulnerability of groundwater resources, it is essential to possess sufficient information on salinization processes. In this sense, the data provided in this work constitute a scientific basis that makes it possible to recognize geogenically and 
anthropogenically salinized areas. It is in the latter where guidelines can be generated to mitigate groundwater salinization. To this end, community participation is essential for the success of long-term management strategies. Communities, as users and beneficiaries of groundwater, must understand the fragility of the resource and become aware of its use [79].

\section{Conclusions}

Bahía San Blas constitutes a representative area of the Atlantic coast of Patagonia where beach ridges were deposited during the Pleistocene and Holocene as a result of sealevel fluctuations. Currently, these ridges emerge, forming positive geoforms composed of coarse-grained sediments that can potentially store freshwater lenses.

Increasing the sampling points in the area of Pleistocene ridges, as well as carrying out detailed studies of the sediments that compose both beach ridges, and defining the variation in water salinity in depth using geophysical methods, provides novel data that make it possible to improve the comprehension of the processes that cause groundwater salinization.

The different methodologies applied in this study allowed us to interpret the different factors and mechanisms responsible for groundwater salinization in the different studied environments. Sedimentological surveys provided data to understand the evolution of the area and the hydrolithological characteristics of the beach ridges. Groundwater EC measurements, along with VES interpretation, allowed us to characterize salinized areas and freshwater lenses morphologically. Similarly, the VES demonstrated changes in the resistivity of the unsaturated zone, responding to the presence, or non-presence, of cementation. In addition, the isotopic and hydrochemical data enabled us to interpret the origin of salinization and the existence of areas where freshening dominates.

Pleistocene beach ridges store brackish groundwater, while Holocene ridges mainly store low-salinity groundwater, with a slight increase in the most populated areas.

The groundwater salinization of Pleistocene ridges responds to processes associated with the geological-geomorphological evolution of the area. Sea level oscillations followed by periods of aridity during the Pleistocene caused the precipitation of carbonates in the gravels composing the Pleistocene ridges, causing their cementation. This cementation restricted rainwater infiltration during the wettest periods and consequently prevented the development of freshwater lenses, thus favoring saline water permanence as a result of ancient marine ingressions. Studies of trace elements or radioactive isotopes will allow the assessment of the presence of paleo-seawater in greater detail in the future; however, both the geological-geomorphological evolution of the area and the data collected support our hypothesis.

On the other hand, the sands and gravels that compose Holocene ridges are not cemented. This allows the high permeability to sediments favoring rainwater infiltration and the development of freshwater lenses. Nevertheless, slight water salinization was detected in the most populated areas associated with water levels decreasing as a result of intensive exploitation.

In this way, it was shown how, in the same area, groundwater salinization can be due both to factors depending on Quaternary geological-geomorphological evolution and to anthropic action. The data provided in this paper are useful for prospecting freshwater resources along the arid Patagonian coast, where Quaternary beach ridge deposits abound and populations experience serious freshwater supply problems.

Author Contributions: Conceptualization, E.C. and M.d.P.Á.; methodology, E.C., C.T. and S.P.; formal analysis, E.C., M.d.P.Á. and S.P.; investigation, E.C., M.d.P.Á. and S.P.; data curation, E.C., M.d.P.Á., S.P. and C.T.; chemical analysis determination C.T.; writing-original draft preparation, E.C. and M.d.P.Á.; writing—review and editing, E.C., M.d.P.Á., S.P., C.T. and P.B.; project administration, M.d.P.Á.; funding acquisition, E.C. and M.d.P.Á. All authors have read and agreed to the published version of the manuscript.

Funding: This research was funded by the Agencia Nacional de Promoción Científica y Tecnológica of Argentina, grant number PICT 2017-1131 and grant number PICT 2019-02421. 
Institutional Review Board Statement: Not applicable.

Informed Consent Statement: Not applicable.

Data Availability Statement: The data presented in this study are available on request from the corresponding author.

Acknowledgments: The authors want to thank Nicolás Scivetti, Lina Videla, and Ignacio Paniagua who collaborated in the field activities and the VES.

Conflicts of Interest: The authors declare no conflict of interest.

\section{References}

1. Vandenbohede, A.; Lebbe, L. Groundwater chemistry patterns in the phreatic aquifer of the central Belgian coastal plain. Appl. Geochem. 2011, 27, 22-36. [CrossRef]

2. Semeniuk, V. Coastal forms and Quaternary processes along the arid Pilbara coast of northwestern Australia. Palaeogeogr. Palaeoclim. Palaeoecol. 1996, 123, 49-84. [CrossRef]

3. Vann, S.; Puttiwongrak, A.; Suteerasak, T.; Koedsin, W. Delineation of Seawater Intrusion Using Geo-Electrical Survey in a Coastal Aquifer of Kamala Beach, Phuket, Thailand. Water 2020, 12, 506. [CrossRef]

4. Ahlhorn, F. Hydrology of (Shallow) Coastal Regions. In Integrated Coastal Zone Management; Springer Vieweg: Wiesbaden, Germany, 2018; pp. 49-62.

5. Lee, J.-Y.; Raza, M.; Park, Y.-C. Current status and management for the sustainable groundwater resources in Korea. Episodes 2018, 41, 179-191. [CrossRef]

6. Collins, W.H.; Easley, D.H. Fresh-water lens formation in an unconfined barrier-island aquifer. JAWRA J. Am. Water Resour. Assoc. 1999, 35, 1-22. [CrossRef]

7. Ruppel, C.; Schultz, G.; Kruse, S. Anomalous Fresh Water Lens Morphology on a Strip Barrier Island. Ground Water 2000, 38, 872-881. [CrossRef]

8. Stuyfzand, P.J. Observations and analytical modeling of freshwater and rainwater lenses in coastal dune systems. J. Coast. Conserv. 2017, 21, 577-593. [CrossRef]

9. Greggio, N.; Giambastiani, B.M.S.; Balugani, E.; Amaini, C.; Antonellini, M. High-Resolution Electrical Resistivity Tomography (ERT) to Characterize the Spatial Extension of Freshwater Lenses in a Salinized Coastal Aquifer. Water 2018, 10, 1067. [CrossRef]

10. Bear, J. Hydraulics of Groundwater; Dover Publications, INC.: Mineola, NY, USA, 1979.

11. de Louw, P.; Eeman, S.; Essink, G.O.; Vermue, E.; Post, V. Rainwater lens dynamics and mixing between infiltrating rainwater and upward saline groundwater seepage beneath a tile-drained agricultural field. J. Hydrol. 2013, 501, 133-145. [CrossRef]

12. Morgan, L.K.; Werner, A.D. Seawater intrusion vulnerability indicators for freshwater lenses in strip islands. J. Hydrol. 2014, 508, 322-327. [CrossRef]

13. Carol, E.; García, L.; Borzi, G. Hydrogeochemistry and sustainability of freshwater lenses in the Samborombón Bay wetland, Argentina. J. S. Am. Earth Sci. 2015, 60, 21-30. [CrossRef]

14. Da Lio, C.; Carol, E.; Kruse, E.; Teatini, P.; Tosi, L. Saltwater contamination in the managed low-lying farmland of the Venice coast, Italy: An assessment of vulnerability. Sci. Total Environ. 2015, 533, 356-369. [CrossRef] [PubMed]

15. Post, V.E.; Groen, J.; Kooi, H.; Person, M.; Ge, S.; Edmunds, W.M. Offshore fresh groundwater reserves as a global phenomenon. Nat. Cell Biol. 2013, 504, 71-78. [CrossRef] [PubMed]

16. Mastrocicco, M.; Colombani, N. The Issue of Groundwater Salinization in Coastal Areas of the Mediterranean Region: A Review. Water 2021, 13, 90. [CrossRef]

17. Antonellini, M.; Mollema, P.N. Impact of groundwater salinity on vegetation species richness in the coastal pine forests and wetlands of Ravenna, Italy. Ecol. Eng. 2010, 36, 1201-1211. [CrossRef]

18. Custodio, E. Aquifères côtières de l'Europe: Une vision generale. Hydrogeol. J. 2010, 18, 269-280. [CrossRef]

19. Pinna, M.S.; Cogoni, D.; Fenu, G.; Bacchetta, G. The conservation status and anthropogenic impacts assessments of Mediterranean coastal dunes. Estuarine Coast. Shelf Sci. 2015, 167, 25-31. [CrossRef]

20. Cellone, F.; Tosi, L.; Carol, E. Estimating the freshwater-lens reserve in the coastal plain of the middle Río de la Plata Estuary (Argentina). Sci. Total Environ. 2018, 630, 357-366. [CrossRef] [PubMed]

21. Giambastiani, B.; Kidanemariam, A.; Dagnew, A.; Antonellini, M. Evolution of Salinity and Water Table Level of the Phreatic Coastal Aquifer of the Emilia Romagna Region (Italy). Water 2021, 13, 372. [CrossRef]

22. Werner, A.D.; Bakker, M.; Post, V.E.; Vandenbohede, A.; Lu, C.; Ataie-Ashtiani, B.; Simmons, C.T.; Barry, D. Seawater intrusion processes, investigation and management: Recent advances and future challenges. Adv. Water Resour. 2013, 51, 3-26. [CrossRef]

23. de Louw, P.G.B.; Eeman, S.; Siemon, B.; Voortman, B.R.; Gunnink, J.; van Baaren, E.S.; Essink, G.H.P.O. Shallow rainwater lenses in deltaic areas with saline seepage. Hydrol. Earth Syst. Sci. 2011, 15, 3659-3678. [CrossRef]

24. Vincent, A.; Violette, S. Why seawater intrusion has not yet occurred in the Kaluvelli-Pondicherry basin, Tamil Nadu, India. Hydrogeol. J. 2017, 25, 1893-1907. [CrossRef]

25. Meisler, H.; Leahy, P.P.; Knobel, L.L. Effect of Eustatic Sea-Level Changes on Saltwater-Freshwater in the Northern Atlantic Coastal Plain; U.S. Geological Survey Water-Supply Paper: Alexandria, VA, USA, 1984; Volume 2255, 28p. 
26. Delsman, J.R.; Hu-A-Ng, K.R.M.; Vos, P.C.; de Louw, P.G.B.; Essink, G.H.P.O.; Stuyfzand, P.J.; Bierkens, M.F.P. Paleo-modeling of coastal saltwater intrusion during the Holocene: An application to the Netherlands. Hydrol. Earth Syst. Sci. 2014, 18, $3891-3905$. [CrossRef]

27. Tran, T.L.; Larsen, F.; Pham, Q.N.; Christiansen, A.V.; Tran, N.; Vu, V.H.; Tran, L.V.; Hoang, V.H.; Hinsby, K. Origin and extent of fresh groundwater, salty paleowaters and recent saltwater intrusions in Red River flood plain aquifers, Vietnam. Hydrogeol. J. 2012, 20, 1295-1313. [CrossRef]

28. Larsen, F.; Tran, L.V.; Van Hoang, H.; Tran, L.T.; Vest Christiansen, A.; Pham, N.Q. Groundwater salinity influenced by Holocene seawater trapped in incised valleys in the Red River delta plain. Nat. Geosci. 2017, 10, 376-381. [CrossRef]

29. Shrestha, M.K.; Recknagel, F.; Frizenschaf, J.; Meyer, W. Assessing SWAT models based on single and multi-site calibration for the simulation of flow and nutrient loads in the semi-arid Onkaparinga catchment in South Australia. Agric. Water Manag. 2016, 175, 61-71. [CrossRef]

30. Hu, W.; Wang, Y.; Li, H.; Huang, M.; Hou, M.; Li, Z.; She, D.; Si, B. Dominant role of climate in determining spatio-temporal distribution of potential groundwater recharge at a regional scale. J. Hydrol. 2019, 578, 124042. [CrossRef]

31. Kammoun, S.; Trabelsi, R.; Re, V.; Zouari, K. Coastal Aquifer Salinization in Semi-Arid Regions: The Case of Grombalia (Tunisia). Water 2021, 13, 129. [CrossRef]

32. Clark, I. Groundwater Geochemistry and Isotopes; CRC Press: Boca Raton, FL, USA, 2015.

33. Bagheri, R.; Nosrati, A.; Jafari, H.; Eggenkamp, H.; Mozafari, M. Overexploitation hazards and salinization risks in crucial declining aquifers, chemo-isotopic approaches. J. Hazard. Mater. 2019, 369, 150-163. [CrossRef]

34. Nassir, S.S.A.; Loke, M.H.; Lee, C.-Y.; Nawawi, M.N.M. Salt-water intrusion mapping by geoelectrical imaging surveys. Geophys. Prospect. 2000, 48, 647-661. [CrossRef]

35. Hayley, K.; Bentley, L.R.; Gharibi, M. Time-lapse electrical resistivity monitoring of salt-affected soil and groundwater. Water Resour. Res. 2009, 45. [CrossRef]

36. Zarroca, M.; Bach, J.; Linares, R.; Pellicer, X.M. Electrical methods (VES and ERT) for identifying, mapping and monitoring different saline domains in a coastal plain region (Alt Empordà, Northern Spain). J. Hydrol. 2011, 409, 407-422. [CrossRef]

37. Revil, A.; Karaoulis, M.; Johnson, T.; Kemna, A. Review: Some low-frequency electrical methods for subsurface characterization and monitoring in hydrogeology. Hydrogeol. J. 2012, 20, 617-658. [CrossRef]

38. Tomaszkiewicz, M.; Najm, M.A.; El-Fadel, M. Development of a groundwater quality index for seawater intrusion in coastal aquifers. Environ. Model. Softw. 2014, 57, 13-26. [CrossRef]

39. Amiri, V.; Nakhaei, M.; Lak, R.; Kholghi, M. Geophysical, isotopic, and hydrogeochemical tools to identify potential impacts on coastal groundwater resources from Urmia hypersaline Lake, NW Iran. Environ. Sci. Pollut. Res. 2016, 23, 16738-16760. [CrossRef] [PubMed]

40. Mirzavand, M.; Ghasemieh, H.; Sadatinejad, S.J.; Bagheri, R. An overview on source, mechanism and investigation approaches in groundwater salinization studies. Int. J. Environ. Sci. Technol. 2020, 17, 2463-2476. [CrossRef]

41. Sae-Ju, J.; Chotpantarat, S.; Thitimakorn, T. Hydrochemical, geophysical and multivariate statistical investigation of the seawater intrusion in the coastal aquifer at Phetchaburi Province, Thailand. J. Asian Earth Sci. 2020, 191, 104165. [CrossRef]

42. Alvarez, M.P.; Trovatto, M.; Hernández, M.; González, N. Groundwater flow model, recharge estimation and sustainability in an arid region of Patagonia, Argentina. Environ. Earth Sci. 2012, 66, 2097-2108. [CrossRef]

43. Arzac, R.G.; Diaz, J.L. Tres Modelos Hidrogeologicos de la Patagonia Extrandina Provincia de Santa Cruz-República Argentina. Águas Subterráneas. 1990. Available online: https://aguassubterraneas.abas.org/asubterraneas/article/view/24538 (accessed on 20 September 2021).

44. Rutter, N.; Schnack, E.J.; Del Rio, J.; Fasano, J.L.; Isla, F.; Radtke, U. Correlation and dating of Quaternary littoral zones along the Patagonian coast, Argentina. Quat. Sci. Rev. 1989, 8, 213-234. [CrossRef]

45. Rostami, K.; Peltier, W.; Mangini, A. Quaternary marine terraces, sea-level changes and uplift history of Patagonia, Argentina: Comparisons with predictions of the ICE-4G (VM2) model of the global process of glacial isostatic adjustment. Quat. Sci. Rev. 2000, 19, 1495-1525. [CrossRef]

46. Pedoja, K.; Regard, V.; Husson, L.; Martinod, J.; Guillaume, B.; Fucks, E.; Iglesias, M.; Weill, P. Uplift of quaternary shorelines in eastern Patagonia: Darwin revisited. Geomorphology 2011, 127, 121-142. [CrossRef]

47. Isla, F. Coastal barriers from Argentina: Buenos Aires, Patagonia and Tierra del Fuego. Quat. Environ. Geosci. 2017, 8. [CrossRef]

48. Rutter, N.; Radtke, U.; Schnack, E. Comparison of ESR and amino acid data in correlating and dating quaternary shorelines along the Patagonian coast, Argentina. J. Coast. Res. 1990, 6, 391-394.

49. Fucks, E.; Charó, M.; Pisano, F. Aspectos estratigráficos y geomorfológicos del sector oriental patagónico bonaerense. Rev. Soc. Geol. Esp. 2012, 25, 29-44.

50. Misseri, L.; Cellone, F.; Bouza, P.; Alvarez, M.P.; Carol, E. Geohidrología de un sector de la marisma de Bahía San Blas. Rev. Soc. Geol. Esp. 2020, 5, 500-509. [CrossRef]

51. Instituto Geográfico Nacional (IGN). Available online: https:/ / www.ign.gob.ar/NuestrasActividades/Geodesia/ModeloDigitalElevaciones/ Introduccion (accessed on 25 June 2021).

52. Zohdy, A. A new method for the automatic interpretation of Sclumberger and Wenner sounding curve. Geophysics 1989, 54, 245-253. [CrossRef]

53. Maillet, R. The fundamental equations of electrical prospecting. Geophysics 1947, 12, 529-556. [CrossRef] 
54. Johansen, H.K. An interactive computer/graphic-display-terminal system for interpretation of resistivity soundings. Geophys. Prospect. 1975, 23, 449-458. [CrossRef]

55. American Public Health Association (APHA). Standard Methods for the Examination of Water and Wastewater, 19th ed.; American Public Health Association; American Water Works Association; Water Environment Federation: Washington, DC, USA, 1998.

56. Parkhurst, D.L.; Appelo, C.A.J. User's Guide to PHREEQC (Version 2): A Computer Program for Speciation, Batch-Reaction, OneDimensional Transport, and Inverse Geochemical Calculations; Water-Resources Investigations Report 99-4259; USGS Publications Warehouse: Washington, DC, USA, 1999; Volume 99, pp. 1-312.

57. Gonfiantini, R. Standards for stable isotope measurements in natural compounds. Nat. Cell Biol. 1978, 271, 534-536. [CrossRef]

58. Giménez-Forcada, E. Dynamic of Sea Water Interface using Hydrochemical Facies Evolution Diagram. Ground Water 2010, 48, 212-216. [CrossRef] [PubMed]

59. Martínez, D.E.; Quiroz, O.M.; Dapeña, C.; Glok-Galli, M.; Massone, H.E.; Ferrante, A. Caracterización isotópica e hidroquímica de las precipitaciones en el sector sur de Tandilia. In Proceedings of the VII Congreso Argentino de Hidrogeología y V Seminario Hispano-Latinoamericano sobre Temas Actuales de la Hidrología Subterránea, Calidad y Contaminación de Agua Subterránea, Salta, Argentina, 21 October 2011; pp. 369-376.

60. Alvarez, M.D.P.; Funes, D.; Dapeña, C.; Bouza, P.J. Origin and hydrochemical characteristics of groundwater in the Northeastern Patagonia, Argentina: The relationship with geomorphology and soils. Environ. Earth Sci. 2020, 79, 1-14. [CrossRef]

61. Bouza, P.J. Paleosuelos en cordones litorales de la Formación Caleta Valdés, Pleistoceno superior, NE del Chubut. RAGA 2014, 71, $1-10$.

62. Bouza, P.J. Génesis de las acumulaciones de carbonatos en Aridisoles Nordpatagónicos: Su significado paleopedológico. RAGA 2012, 69, 298-313.

63. Tanner, L.H. Continental carbonates as indicators of paleoclimate. In Carbonates in Continental Settings: Geochemistry, Diagenesis and Applications; En Alonso-Zarza, A.M., Tanner, L.H., Eds.; Developments in Sedimentology; Elsevier: Amsterdam, The Netherlands, 2010; Volume 62, pp. 179-214.

64. Hillel, D.; Baker, R.S. A descriptive theory of fingering during infiltration into layered soils. Soil Sci. 1988, 146, 51-56. [CrossRef]

65. Samani, Z.; Cheraghi, A.; Willardson, L. Water Movement in Horizontally Layered Soils. J. Irrig. Drain. Eng. 1989, 115, 449-456. [CrossRef]

66. Stuart, D.M.; Dixon, R.M. Water Movement and Caliche Formation in Layered Arid and Semiarid Soils. Soil Sci. Soc. Am. J. 1973, 37, 323-324. [CrossRef]

67. Kooi, H.; Groen, J. Geological processes and the management of groundwater resources in coastal areas. Neth. J. Geosci. 2003, 82, 31-40. [CrossRef]

68. Morrissey, S.K.; Clark, J.F.; Bennett, M.; Richardson, E.; Stute, M. Groundwater reorganization in the Floridan aquifer following Holocene sea-level rise. Nat. Geosci. 2010, 3, 683-687. [CrossRef]

69. Lee, S.; Currell, M.; Cendón, D. Marine water from mid-Holocene sea level highstand trapped in a coastal aquifer: Evidence from groundwater isotopes, and environmental significance. Sci. Total Environ. 2016, 544, 995-1007. [CrossRef] [PubMed]

70. Logan, W.S.; Auge, M.P.; Panarello, H.O. Bicarbonate, Sulfate, and Chloride Water in a Shallow, Clastic-Dominated Coastal Flow System, Argentina. Ground Water 1999, 37, 287-295. [CrossRef]

71. Santucci, L.; Carol, E.; Kruse, E. Quaternary marine ingressions as indicated by hydrogeochemical evidence in the semi-confined aquifer of the littoral of the Río de la Plata, Argentina. Quat. Res. 2017, 88, 160-167. [CrossRef]

72. Santucci, L.; Carol, E.; Kruse, E. Identification of palaeo-seawater intrusion in groundwater using minor ions in a semi-confined aquifer of the Río de la Plata littoral (Argentina). Sci. Total Environ. 2016, 566-567, 1640-1648. [CrossRef] [PubMed]

73. El Yaouti, F.; El Mandour, A.; Khattach, D.; Benavente, J.; Kaufmann, O. Salinization processes in the unconfined aquifer of Bou-Areg (NE Morocco): A geostatistical, geochemical, and tomographic study. Appl. Geochem. 2009, 24, 16-31. [CrossRef]

74. Wang, Y.; Jiao, J.J. Origin of groundwater salinity and hydrogeochemical processes in the confined Quaternary aquifer of the Pearl River Delta, China. J. Hydrol. 2012, 438-439, 112-124. [CrossRef]

75. Vallejos, A.; Sola, F.; Yechieli, Y.; Pulido-Bosch, A. Influence of the paleogeographic evolution on the groundwater salinity in a coastal aquifer. Cabo de Gata aquifer, SE Spain. J. Hydrol. 2018, 557, 55-66. [CrossRef]

76. Gao, M.S.; Zheng, Y.M.; Liu, S.; Wang, S.T.; Kong, X.H.; Zhao, J.M.; Guo, F. Palaeogeographic condition for origin of underground brine in southern coast of Laizhou Bay, Bohai Sea. Geol. Rev. 2015, 61, 393-400.

77. Liu, S.; Tang, Z.; Gao, M.; Hou, G. Evolutionary process of saline-water intrusion in Holocene and Late Pleistocene groundwater in southern Laizhou Bay. Sci. Total Environ. 2017, 607-608, 586-599. [CrossRef] [PubMed]

78. Walraevens, K.; Van Camp, M.; Lermytte, J.; Van Der Kemp, W.J.M.; Loosli, H.H. Pleistocene and Holocene groundwaters in the freshening Ledo-Paniselian aquifer in Flanders, Belgium. Geol. Soc. London Spéc. Publ. 2001, 189, 49-70. [CrossRef]

79. Gleeson, T.; VanderSteen, J.; Sophocleous, M.A.; Taniguchi, M.; Alley, W.M.; Allen, D.; Zhou, Y. Groundwater sustainability strategies. Nat. Geosci. 2010, 3, 378-379. [CrossRef]

80. Mahlknecht, J.; Merchán, D.; Rosner, M.; Meixner, A.; Ledesma-Ruiz, R. Assessing seawater intrusion in an arid coastal aquifer under high anthropogenic influence using major constituents, Sr and B isotopes in groundwater. Sci. Total Environ. 2017, 587-588, 282-295. [CrossRef] [PubMed]

81. Motevalli, A.; Moradi, H.R.; Javadi, S. A Comprehensive evaluation of groundwater vulnerability to saltwater up-coning and sea water intrusion in a coastal aquifer (case study: Ghaemshahr-juybar aquifer). J. Hydrol. 2018, 557, 753-773. [CrossRef] 
82. Van de Plassche, O. Coastal Evolution: Late Quaternary Shoreline Morphodynamics; Cambridge University Press: Cambridge, UK, 1994.

83. Cong-Thi, D.; Dieu, L.; Thibaut, R.; Paepen, M.; Ho, H.; Nguyen, F.; Hermans, T. Imaging the Structure and the Saltwater Intrusion Extent of the Luy River Coastal Aquifer (Binh Thuan, Vietnam) Using Electrical Resistivity Tomography. Water 2021, 13, 1743. [CrossRef] 